\title{
Dünya'da ve Türkiye'de Anadili Eğitiminde Güncel Yönelimlerin Öğretim Üyelerinin Görüşleri Doğrultusunda Değerlendirilmesi
}

\author{
Analysis of Current Trends in Mother Tongue Education in the World and Turkey in Terms of Academicians \\ Özgür Babayiğit ${ }^{\mathrm{a}^{*}}$ \\ ${ }^{a}$ Dr. Öğr. Üyesi, Yozgat Bozok Üniversitesi, Eğitim Fakültesi, Temel Eğitim Bölümü, 66100, Yozgat/Türkiye. \\ ORCID: 0000-0001-6123-0609
}

\begin{tabular}{l} 
MAKALE BİLGİSİ \\
\hline Makale Geçmişi: \\
Başvuru tarihi: 14 Eylül 2018 \\
Düzeltme tarihi: 03 Ekim 2018 \\
Kabul tarihi: 31 Ekim 2018 \\
\hline Anahtar Kelimeler: \\
Anadili \\
Dünya \\
Eğitim \\
Türkiye \\
Yönelim
\end{tabular}

\section{A R T I CLE INFO}

\section{Article history:}

Received 14 September 2018

Received in revised form 03 October 2018 Accepted 31 October 2018

\section{Keywords:}

Mother Tongue

World

Education

Turkey

Trend
ÖZ

Bu araştırmanın amacı Dünya'da ve Türkiye'de anadili eğitiminde güncel yönelimlerin öğretim üyelerinin görüşleri doğrultusunda değerlendirilmesidir. Araştırma, nitel araştırma yöntemlerinden olgu bilim türündedir. Verilerin toplanması amacıyla, Türkiye'de görev yapan beş öğretim üyesiyle yarı yapılandırılmış görüşme formu ile görüşmeler yapılmıştır. Yurt dışındaki iki öğretim üyesiyle, elektronik posta ile iletişim kurulmuştur Verilerin analizinde içerik analizi yöntemi kullanılmıştır. Araştırma sonucunda akıcı okuma ve konuşma konusunun anadili eğitiminde ağırlık kazandığı tespit edilmiştir. Kalem yerine klavye kullanımı güncel yönelimlerden bir diğeridir. Üst düzey bilişsel becerileri geliştirme güncel yönelimler arasındadır.

\section{Giriş}

Bireylerde ana dili edinimi anne karnında başlamaktadır. Doğumdan ilkokula başlayana kadar çocukta dinleme ve konuşma becerileri belirli bir ölçüde gelişmektedir. İlkokula başlama ile birlikte okuma ve yazma becerileri kazanılmaktadır. Bireyin eğitim-öğretim yaşamı boyunca ana dili eğitimi devam etmektedir. Ana dili eğitimi aynı zamanda düşünmeyi geliştirmektedir. Yapılan bu araştırmanın giriş bölümünde öncelikle ana dili kavramı açıklanmıştır. Ardından ana dili eğitiminin önemi üzerinde durulmuştur. Son olarak ana dili öğretimi konusuna değinilmiştir.

Ana dili, bireyin ailesinden ve içerisinde yaşadığı toplumdan edindiği dil demektir (TDK, 2018). İnsanın genellikle annesiyle ve bebeklik döneminde bir arada olduğu dil topluluğunun üyeleriyle etkileşime girerek edindiği dildir. Asıl dil, birinci dil olarak da nitelendirilmektedir (Eker, 2015: 9). Anadili, bireyin içerisinde doğup yetiştiği aile veya

\footnotetext{
* Sorumlu yazar/Corresponding author.

e-posta: ozgur.babayigit@bozok.edu.tr
} 
toplumda, gelişigüzel bir kültürlenme sonucunda öğrendiği ilk dildir (Yaşar, 2008: 3). Anadili, bireylerin doğumla birlikte yakın çevresinden öğrendiği, zamanla iletişimde bulunduğu sosyal çevrelerle geliştirdiği dildir (Ata, 2004: 7). Bir toplum ile kültür içerisinde, ilk olarak ailede ve yakın çevrede kazanılan, ardından okulda pekiştirilen ve geliştirilen dile anadili denilmektedir (Topbaş, 1998: 10). Yapılan anadili tanımları incelendiğinde, bireyin yaşamının ilk yıllarına vurgu yapıldığı görülmektedir. Bununla birlikte yaşamın ilk yıllarında bireyin iletişimde olduğu ailesi ve toplum dikkat çekmektedir.

Anadili gelişimi üç seviyede gerçekleşmektedir. İlk olarak bebekte fonemler seviyesinde başlamaktadır. İkinci olarak sözcükler seviyesine daha sonra üçüncü ve son olarak cümle birimleri veya sözdizimi düzeyine geçmektedir (NolenHoeksema, Fredrickson, Loftus ve Wagenaar, 2009: 326). Çocuklar diğer insanları dinleyerek ve diğer insanlarla konuşarak anadilini öğrenmektedirler. Anadili ayrıca düşünme sürecinin bir parçasıdır (Dean, 2005: 34). Anadili kazanımı bebeğin doğumu ile birlikte anne-bebek ve diğer aile üyelerinin etkileşimiyle başlamaktadır. Dil kazanımı 1218 aylar arasında ilk sözcüklerle başlamaktadır. Okul öncesi dönemde anadilinin biçim, içerik ve kullanımı gelişmektedir. Çocuk, anadilini konuşan başka bireyleri dinlemekte, onların deneyimleri ve düşüncelerinden yararlanmaktadır. $\mathrm{Bu}$ süreçte dil düşünceyi, düşünce de dili sürekli etkilemekte ve birbirini geliştirmektedir (Topbaş, 1998: 10). Çocuklar ana dillerini öğrenmeye doğuştan yatkın olarak ve hazır doğmaktadırlar. Dili öğrenme becerisi çocuk doğduğunda beyninde var olan bir beceridir. Bu beceri dil öğrenme aygitı olarak bilinmektedir (Demirezen, 2003: 11). Anadili gelişiminin yanı sıra, anadilinin önemli işlevleri bulunmaktadır.

Anadili; bireyin bilgi ve becerilerini artırmada, içinde bulunduğu topluma uyum sağlamada ve kişiliğinin gelişmesinde çok önemli bir işlevi yerine getirmektedir (Yaşar, 2008: 3). İnsanlar, anadili ile üyesi bulunduğu toplumla iletişim kurmaktadırlar. Anadiliyle o toplumun bir parçası olmaktadırlar (Ata, 2004: 7).

Tüm ülkelerin eğitim sistemlerinde anadili öğretimine büyük bir önem verilmektedir. Daha verimli ve etkili anadili öğretimine ulaşabilmenin yolları aranmaktadır (Hamzadayı, 2010: 39). Anadili eğitimi okullarda kasıtlı kültürleme olarak tanımlanan öğretim ile üst dil becerilerinin kazandırılmasına dönüşmektedir. Anadili okula başlayana kadar doğal olarak kendiliğinden kazanılmaktadır. Okulda ise, kazanılan anadil aracılığıyla dilin kuralları, anadilinin işlevi ve doğru kullanımı öğrencilere öğretilmektedir (Topbaş, 1998: 10). Temel dil becerilerinin beş veya altı yaşlarına kadar kazanıldığ 1 , dili ustalıkla kullanabilme becerilerinin ise bu yaşlardan sonra gelişmeye başladı̆̆ı ve on yaşına kadar sürdüğü kabul edilmektedir (Demir ve Yapıc1, 2007: 179). Anadili eğitimi ve öğretimi gerçekleştirilmediğinde birey çevresinde bulduklarıyla ve yöresel söyleyişlerle dokunmuş bir dil kurmaktadır. Bireylerin çocukluk çağında edindiği yanlış dil kullanımı ileri yaşlarda doğrusunu kazandırmak bazen mümkün olmamaktadır (Demir ve Yapıcı, 2007: 179). Bireyin kendini gerçekleştirme ve etkili iletişim kurabilmesinde anadili eğitiminin büyük önemi bulunmaktadır. Bireyin, anadili iletişim yeterliği ile onun okuldaki akademik başarısı arasında olumlu ilişki vardır (Topbaş, 1998: 11). Anadili öğretimi, bireyin anlama ve anlatma becerilerini geliștirmeyi amaçlamaktadır. Dilbilgisi konu alanı, anlama ve anlatmayı kolaylaştırmada yardımcı çalışma alanıdır (Hamzadayı, 2010: 39). Anadili öğretimi, anadili ders kitaplarındaki metinler aracılığıyla yapılmaktadır. $\mathrm{Bu}$ metinlerin etrafında yer alan çeşitli görseller ile kavratılmaya çalışılmaktadır (Batur, 2010: 180). Günlük yaşamda ve okul yaşamında anadilini iyi kullanmak, inceliklerini bilmek, düşünceleri düzgün olarak ifade etmek okul başarısını ve yaşamdaki başarıyı getirmektedir. Anadilini eksik olarak öğrenen veya öğrenemeyen birey eksik yetişiyor demektir. Anadilinde eksik olan bireylerin bilim, sanat üretmesi mümkün değildir (Çelebi, 2006: 300). Anadili öğretiminin önemi açıklandıktan sonra, araştırmanın problemi üzerinde durulmuştur.

Dünya'da ve Türkiye'de anadili eğitimine yönelik olarak yapılan güncel araştırmalar incelendiğinde genellikle derleme türü çalışmaların ağırlık kazandığı görülmektedir. Çelebi (2006) tarafından yapılan araştırmada, anadilinin bir ulusun kimliğini, kültürünü ve benliğini yansıtan bir araç olduğu belirtilmektedir. Anadili öğretiminin tüm ülkelerde tartışılan en önemli konular arasında olduğu vurgulanmaktadır. Hamzadayı (2010) tarafindan yapılan araştırmada Türkçe dersi $(6,7,8$. sınıflar) öğretim programının tasarımındaki yapılandırmacı öğrenme kuramı incelenmiştir. Yapılandırmacı kuram odaklanılarak düzenlenen öğretim uygulamalarının, anadili öğretiminin doğasıyla tam olarak uyuşmadığı tespit edilmiştir. Eaton (2010) tarafindan yapılan araştırma sonucunda, günümüzde dil laboratuvarlarının kullanımının azaldığı belirtilmiştir. Ayrıca dil laboratuvarlarının etkili ve verimli olmadığı vurgulanmıştır. Dil öğretiminde süreç değerlendirmenin önemindeki artış belirtilmiştir. Dil öğrenmede konuşma aktivitelerinde artış belirtilmiştir. Son olarak dil öğreniminde teknoloji kullanımındaki artış vurgulanmıştır. Yapılan bu araştırma ile önceki çalışmalardan farklı olarak dünyadaki ve Türkiye'deki anadili eğitimine yönelik değişimler incelenmiştir. Anadili eğitiminin, dünyada ve Türkiye'de ne şekilde eğilim gösterdiği irdelenmiştir. Gelişmiş dünya ülkeleriyle Türkiye'de anadili eğitim sistemleri karşılaştırmalı olarak incelenmiştir.

Yapılan bu araştırmanın amacı Dünya'da ve Türkiye'de anadili eğitimine yönelik eğilimlerin incelenmesidir. Dünyanın gelişmiş ülkelerinde ve Türkiye'de anadili eğitiminde yönelimlerin neler olduğu ortaya konulmuştur. Yapılan bu araştırma, gelişmiş ülkelerdeki ve Türkiye'deki anadili öğretimindeki yönelimlerin belirlenmesi açısından önemlidir. Gelişmiş dünya ülkelerindeki (Amerika, Almanya, Avusturya, İngiltere, Fransa vb.) anadili eğitimi yönelimlerini bilmek, bu yönelimleri Türkiye'deki anadili eğitimi çalışmalarıyla kıyaslamak açısından önemlidir. Yapılan bu araştırmanın öncelikle Millî Eğitim Bakanlığı Türkçe Dersi Öğretim Programı hazırlama komisyonuna, Türk dili ve edebiyatı dersi öğretim programı hazırlama komisyonuna faydalı olacağı düşünülmektedir. Ayrıca ilk okuma ve yazma öğretimi, Türkçe öğretimi, Türk dili ve edebiyatı öğretimi alanlarında çalışan araştırmacılar için faydalı olacağı düşünülmektedir.

\section{Yöntem}

$\mathrm{Bu}$ bölümde çalışmanın modelinden, çalışma grubundan, veri toplama aracindan, verilerin toplanmasından, verilerin analizinden ve geçerlikten-güvenirlikten bahsedilmektedir. 


\subsection{Araştırma Modeli}

Dünya'da ve Türkiye'de anadili eğitimindeki yönelimlerin incelendiği bu araştırma, nitel araştırma yöntemlerinden olgu bilim türündedir. Olgu bilim deseni farkında olduğumuz ancak derinlemesine ve ayrıntılı bir anlayışa sahip olmadığımız olgulara odaklanmaktadır. Bize tümüyle yabanc1 olmayan aynı zamanda da tam anlamını kavrayamadığımız olguları araştırmayı amaçlayan çalışmalar için fenomenoloji uygun bir araştırmadır (Yıldırım ve Şimşek, 2006: 72). Olgu bilim insanların fenomenleri nasıl tecrübe ettiklerinin metodolojik, özenli ve derinlemesine bir şekilde resmedilmesini ve betimlenmesidir (Patton, 2014: 104; Gliner, Morgan ve Leech, 2015: 97). Olgu bilim, bir fenomenin bireylerin ya da belli bir gurubun deneyimleri açısından tanımlanmasıdır (Christensen, Johnson ve Turner, 2015: 408). Anadili konusunda uzman öğretim üyelerinin, dünyada ve ülkelerinde anadili eğitimindeki yönelimlere ilişkin görüşlerini almak amacıyla görüşme yöntemi kullanılmıştır. Görüşme, katılımcıların özel bir konu hakkındaki düşüncelerinin açık uçlu sorularla alınmasıdır (McMillan ve Schumacher, 2006: 350).

\subsection{Araştırma Grubu}

Araştırma grubunun belirlenmesinde amaçlı örnekleme yöntemlerinden kolay ulaşılabilir durum örneklemesi ile ölçüt örnekleme yöntemleri kullanılmıştır (Yıldırım ve Şimşek, 2006: 112, 113). Ölçüt olarak, anadili eğitimi konusunda uzman olan öğretim üyeleri belirlenmiş̧tir. Görüşme yapılan öğretim üyelerine ilişkin demografik veriler Tablo 1'de sunulmaktadır.

Tablo 1. Görüşme yapılan öğretim üyeleri

\begin{tabular}{|c|c|c|}
\hline Unvan & Görev Yapılan Üniversite & Anabilim Dal1 \\
\hline Prof. Dr. & $\begin{array}{l}\text { National Louis } \\
\text { Üniversitesi/Chicago }\end{array}$ & Dil Eğitimi \\
\hline Doç. Dr. & Y1ldız Teknik Üniversitesi & Sınıf Öğretmenliği \\
\hline Profesör & UNC Charlotte's & Okuma ve Temel \\
\hline Asistan1 & University/Charlotte & Eğitim \\
\hline Dr. Öğr. Üyesi & Yozgat Bozok Üniversitesi & Türkçe Eğitimi \\
\hline Dr. Öğr. Üyesi & Yozgat Bozok Üniversitesi & Sınıf Öğretmenliği \\
\hline Dr. Öğr. Üyesi & Yozgat Bozok Üniversitesi & $\begin{array}{l}\text { İngilizce } \\
\text { Öğretmenliği }\end{array}$ \\
\hline Dr. Öğr. Üyesi & Yozgat Bozok Üniversitesi & $\begin{array}{l}\text { Okul Öncesi } \\
\text { Öğretmenliği }\end{array}$ \\
\hline
\end{tabular}

Tablo 1 incelendiğinde, görüşme yapılan öğretim üyelerinin ikisinin Amerika Birleşik Devletlerinde görev yaptığı, beş öğretim üyesinin Türkiye'de görev yaptığı görülmektedir.

\subsection{Veri Toplama Arac1}

Araştırmada veri toplama aracı olarak yarı yapılandırılmış görüşme formu kullanılmıştır. Yarı yapılandırılmış görüşme formunu oluşturmak amacıyla, öncelikle anadili eğitimiyle ilgili alan yazın incelenmiştir. Alan yazın incelenmesinin ardından oluşturulan yarı yapılandırılmış görüşme formu, nitel araştırma yöntemleri konusunda uzman bir öğretim üyesi ile Türkçe öğretimi alanında uzman bir öğretim üyesinin görüşlerine sunulmuştur. Uzman görüşleri sonrasında, yarı yapılandırılmış görüş̧me formunda çeşitli düzeltme, ekleme ve çıkarmalar yapılııştır. Hazırlanan yarı yapılandırılmış görüşme formu pilot olarak Türkçe öğretimi alanında çalışan doktor öğretim üyesine uygulanmıştır. Pilot uygulamanın ardından yarı yapılandırılmış görüşme formuna son şekli verilmiştir. Yarı yapılandırılmış görüşme formu iki bölümden oluşmaktadır. İlk bölümde anadili eğitimi alanında uzman öğretim üyesinin demografik özelliklerini belirlemeye yönelik sorular sorulmuştur. İkinci bölümde ise anadili eğitiminde dünyada ve ülkelerindeki yönelimler sorulmuştur. Görüşme soruları şunlardır: 1 Dünyada anadili eğitimindeki güncel yönelimler nelerdir? Açıklar mısınız? 2. Türkiye'de anadili eğitimindeki güncel yönelimler nelerdir? Belirtir misiniz? 3. Dünya ülkelerinde anadili eğitim programlarında nasıl bir ilerleme mevcut? 4. Türkiye'deki anadili eğitim programlarında nasıl bir yönelim görüyorsunuz?

\subsection{Verilerin Toplanmasi}

Verilerin toplanması amacıyla, Türkiye'de görev yapan beş öğretim üyesiyle yarı yapılandırılmış görüşme formu ile görüşmeler yapılmıştır. Yapılan görüşmeler ses kayıt cihazıyla kaydedilmiştir. Görüşmeler ortalama on beş dakika sürmüştür. Toplamda 93 dakika görüşme yapılmıştır. Yurtdışında görev yapan anadili eğitimi konusunda çalışan 56 akademisyenden konu ile ilgili görüşlerini almak amacıyla elektronik posta gönderilmiş̧ir. Maalesef bu elektronik postaların sadece ikisine dönüş olmuştur. Yurt dışındaki iki öğretim üyesiyle, elektronik posta ile iletişim kurulmuştur. Elektronik posta ile görüşleri alınmıştır.

\subsection{Verilerin Analizi}

Verilerin analizinde içerik analizi yöntemi kullanılmıştır. İçerik analizi, verilere dayalı olarak tanımlama, analiz ve temaları sunma aşamalarını içeren bir metottur (Braun ve Clarke, 2006: 79). Verilerin analizinde, Merriam (2013: 165184) tarafindan belirtilen içerik analizindeki aşamalar izlenmiştir. Veriler öncelikle kodlanmıştır. Ardından kodlardan kategorilere ulaşılmışıtır. Ulaşılan kategorilerden ise temalara ulaşılmıştır. Veriler belirli temalar altında toplanarak, okuyucunun kolayca anlayabileceği bir şekilde sunulmuştur. İçerik analizi sonucunda ulaşılan kodlar ve temalar Tablo 2'de sunulmaktadır.

Araştırmanın geçerlilik boyutunda uzman incelemesi yöntemi kullanılmıştır. Türkçe öğretimi alanında uzman doçent doktor öğretim üyesi, araştırma sürecinin planlanmasından sonuçlanmasına kadar süreci incelemiştir. Araştırmanın güvenirlik boyutunda, araştırmacı tarafından planlananlar ve gerçekleştirilenler nitel araştırma yöntemleri konusunda uzman bir öğretim üyesi ile sürecin planlanmasından sonuçlanmasına kadar paylaşılmıştır. Verilerin içerik analizi sürecinde, araştırmacı tarafindan ve Türkçe öğretimi alanında uzman bir doktor öğretim üyesi tarafından kodlamalar yapılmıştır. Kodlanan verilerin güvenirliği için Miles ve Huberman (2015: 64) tarafindan geliştirilen güvenirlik formülü [Güvenirlik=Görüş birliği sayısı / (Toplam görüş birliği + Görüş ayrıllğı sayısı)] kullanılmıştır. Güvenirlik formülü sonucunda, güvenirlik=.91 olarak bulunmuştur. $\mathrm{Bu}$ güvenirlik katsayısı yapılan kodlamaların güvenilir olduğunu göstermektedir (Miles ve Huberman, 2015: 64). 
Tablo 2. Ulaşılan kodlar ve temalar

\begin{tabular}{|c|c|c|}
\hline Ulaşılan Kodlar & Ulaşılan Kategoriler & Ulaşılan Temalar \\
\hline $\begin{array}{l}\text { - Akıcılık } \\
\text { - Akıcı okuma } \\
\text { - Akıcı konuşma } \\
\text { - Dinleme }\end{array}$ & $\begin{array}{l}\text { - Akıcılık } \\
\text { - Akıcıllğın önemi }\end{array}$ & $\begin{array}{l}\text { Akıc1 okuma ve } \\
\text { konuşma }\end{array}$ \\
\hline $\begin{array}{l}\text { - Teknoloji } \\
\text { - Televizyon } \\
\text { - Bilgisayar } \\
\text { - Sosyal ağlar } \\
\end{array}$ & $\begin{array}{l}\text { - Teknoloji } \\
\text { - Sosyal ağlar }\end{array}$ & Teknoloji kullanımı \\
\hline $\begin{array}{l}\text { - Ses yöntemi } \\
\text { - Okuma öğretimi } \\
\text { - Yazma öğretimi } \\
\end{array}$ & $\begin{array}{l}\text { - Seslerle öğretim } \\
\text { - Okuma yazma } \\
\text { öğretimi } \\
\end{array}$ & $\begin{array}{l}\text { Okuma yazma } \\
\text { öğretimine seslerle } \\
\text { başlama }\end{array}$ \\
\hline $\begin{array}{l}\text { - Kelime } \\
\text { - Kelime hazinesi } \\
\text { - Kelime öğrenme } \\
\text { - Düşünme }\end{array}$ & $\begin{array}{l}\text { - Kelime sayısı } \\
\text { - Kelime hazinesi } \\
\text { - Kelime öğretimi }\end{array}$ & $\begin{array}{l}\text { Kelime hazinesinin } \\
\text { geliştirilmesi }\end{array}$ \\
\hline $\begin{array}{l}\text { - Okuma sevgisi } \\
\text { - Yazma sevgisi } \\
\text { - Okuma alışkanlığ1 } \\
\text { - Yazma alışkanlığ } \\
\end{array}$ & $\begin{array}{l}\text { - Okuma sevgi ve } \\
\text { alışkanlığı } \\
\text { - Yazma sevgi ve } \\
\text { alışkanlığı } \\
\end{array}$ & $\begin{array}{l}\text { Okuma yazma sevgi } \\
\text { ve alışkanlığ } 1\end{array}$ \\
\hline $\begin{array}{l}\text { - Medya } \\
\text { - Televizyon } \\
\text { - Bilgisayar } \\
\text { - İzleme } \\
\end{array}$ & $\begin{array}{l}\text { - Medya takip } \\
\text { - Televizyon izleme }\end{array}$ & Medya okuryazarlığ \\
\hline $\begin{array}{l}\text { - Eleştirme } \\
\text { - Eleştirel düşünme } \\
\text {-Eleştirel okuma } \\
\end{array}$ & $\begin{array}{l}\text {-Eleştirel düşünme } \\
\text { • Eleştirel okuma }\end{array}$ & Eleştirel okuma \\
\hline $\begin{array}{l}\text { - Milli } \\
\text { - Kültür } \\
\text { - Değer }\end{array}$ & $\begin{array}{l}\text { - Milli unsurlar } \\
\text { • Milli kültür }\end{array}$ & Millî kültür \\
\hline $\begin{array}{l}\text { - Kalem } \\
\text { - Klavye } \\
\text { - Parmak } \\
\text { - Yazma } \\
\end{array}$ & $\begin{array}{l}\text { - Klavye kullanımı } \\
\text { - Kalem kullanımı }\end{array}$ & $\begin{array}{l}\text { Kalem yerine klavye } \\
\text { kullanımı }\end{array}$ \\
\hline $\begin{array}{l}\text { - Metin } \\
\text { - Metin okuma } \\
\text { - Metinler arasılık } \\
\end{array}$ & $\begin{array}{l}\text { - Metinler arasılık } \\
\text { - Metinler arası } \\
\text { okuma } \\
\end{array}$ & $\begin{array}{l}\text { Metinler aras1 } \\
\text { okuma }\end{array}$ \\
\hline $\begin{array}{l}\text { - Üst düzey } \\
\text { • Düşünce } \\
\text { •Zihinsel beceri }\end{array}$ & $\begin{array}{l}\text { • Üst düzey düşünme } \\
\text { becerileri } \\
\text { • Üst düzey zihinsel } \\
\text { beceri }\end{array}$ & $\begin{array}{l}\text { Üst düzey bilişsel } \\
\text { becerileri geliştirme }\end{array}$ \\
\hline $\begin{array}{l}\text { - Görsellik } \\
\text { - Görsel okuma } \\
\text { - Görsel yazma } \\
\text { - Görseli anlama } \\
\text { - Tablo } \\
\text { - Grafik } \\
\text { - Tabela }\end{array}$ & $\begin{array}{l}\text { - Görsel okuma } \\
\text { - Görsel yazma } \\
\text { - Şekil okuma }\end{array}$ & Görsel okuryazarlık \\
\hline $\begin{array}{l}\text { - Günlük hayat } \\
\text { • İlişkilendirme } \\
\text { • Günlük hayatta } \\
\text { ihtiyaç } \\
\text { • Günlük hayatta } \\
\text { kullanım } \\
\end{array}$ & $\begin{array}{l}\text { • Günlük hayat } \\
\text { • Günlük hayatla } \\
\text { ilişkilendirme }\end{array}$ & $\begin{array}{l}\text { Günlük hayatla } \\
\text { ilişkilendirme }\end{array}$ \\
\hline $\begin{array}{l}\text { - Test } \\
\text { - Süreç } \\
\text { - Süreç } \\
\text { değerlendirme }\end{array}$ & $\begin{array}{l}\text { - Süreç izleme } \\
\text { • Süreç değerlendirme }\end{array}$ & Süreç değerlendirme \\
\hline
\end{tabular}

\section{Bulgular ve Yorumlar}

Yapılan içerik analizi sonucunda ulaşılan temalar Tablo 3'de sunulmaktadır.
Tablo 3. Ulaşılan Temalar

\begin{tabular}{cl}
\hline No & Tamalar \\
\hline 1 & Akıcı Okuma ve Konuşma \\
2 & Teknoloji Kullanımı \\
3 & Okuma Yazma Öğretimine Seslerle Başlama \\
4 & Kelime Hazinesinin Geliştirilmesi \\
5 & Okuma Yazma Sevgi ve Alışkanlığ 1 \\
6 & Medya Okuryazarlığı \\
7 & Eleştirel Okuma \\
8 & Millî Kültür \\
9 & Kalem Yerine Klavye Kullanımı \\
10 & Metinler Arası Okuma \\
11 & Üst Düzey Bilişsel Becerileri Geliştirme \\
12 & Görsel Okuryazarlık \\
13 & Günlük Hayatla İlişkilendirme \\
14 & Süreç Değerlendirme \\
\hline
\end{tabular}

Tablo 3 incelendiğinde, on dört adet temaya ulaşıldığ görülmektedir. Bulgular, belirtilen temalar altında açıklanmıştır. Temalar açıklanırken görüşme yapılan öğretim üyelerinin görüşleri belirtilmiştir.

\section{Akıcı Okuma ve Konuşma}

Dünya'da ve Türkiye'de anadili eğitimine yönelik tespit edilen ilk güncel yönelim akıcı okuma ve konuşma temasıdır. Tema ile ilgili olarak görüşme yapılan öğretim üyelerinin görüşleri şunlardır:

"Son yıllarda ülkemizde akıcı okumaya ă̆ırlı veriliyor. Hızl okuma kavramının yerini akıcı okuma kavramı aldı. Ögrencilerin akıcı okuma ile okuduklarını daha iyi anlayacağına inantlyor." (Öğretim Üyesi 2). “Akıcı konuşma önemli. Bireylerle iletişimde akıcı ve anlaşılır bir şekilde konuşmak anlaşılmak açısından önemli." (Öğretim Üyesi 4).

Öğretim üyelerinin görüşleri incelendiğinde, akıcı okuma ve konuşma konularının ağırlık kazandığı görülmektedir.

\section{Teknoloji Kullanımı}

Dünya'da ve Türkiye'de anadili eğitimine yönelik tespit edilen ikinci güncel yönelim teknoloji kullanımı temasıdır. Tema ile ilgili olarak görüşme yapılan öğretim üyelerinin görüşleri şunlardır:

"Anadili eğitiminde teknoloji kullanımında artış var tüm dünyada ve ülkemizde. Ülkemizde fatih projesi kapsamında tüm dersliklere akıllı tahta yerleştirildi. Ayrica ortaögretimde ögrencilere ücretsiz olarak tablet dağıtıllyor. Bütün bu gelişmeler anadili eğitiminde teknoloji kullanımında artışa neden oldu.” (Öğretim Üyesi 5). "Teknoloji kullanımı eğitimde yaygınlaşmakta. Bu durum anadili eğitiminde de görülmekte. Artık öğrencilerin tamamının elinde cep telefonu var. Evlerinde bilgisayarlar var. Bu durum anadili eğitimini de etkilemekte." (Ögretim Üyesi 3).

Öğretim üyelerinin görüşleri incelendiğinde, anadili eğitiminde teknoloji kullanımının hızla arttığı görülmektedir.

\section{Okuma Yazma Öğretimine Seslerle Başlama}

Dünya'da ve Türkiye'de anadili eğitimine yönelik tespit edilen üçüncü güncel yönelim okuma yazma öğretimine seslerle başlama temasıdır. Tema ile ilgili olarak görüşme yapılan öğretim üyelerinin görüşleri şunlardır: 
"Amerika, Ingiltere gibi ülkelerde okuma öğretimine seslerle başlanmakta. Ülkemizde 2005 yılından beri seslerin ögretimiyle başlanarak okuma yazma ögretiliyor. Cümle yönteminin yerine ses yöntemi getirildi." (Öğretim Üyesi 5).

"Ülkemizde öncelikle dildeki sesler öğretiliyor. Ardından seslerin harfleri ögretiliyor. Daha sonra hece ve kelime oluşturuluyor." (Öğretim Üyesi 3).

Öğretim üyelerinin görüşleri incelendiğinde, okuma yazma öğretimine seslerle başlama eğilimi anlaşılmaktadır.

\section{Kelime Hazinesinin Geliştirilmesi}

Dünya'da ve Türkiye'de anadili eğitimine yönelik tespit edilen dördüncü güncel yönelim kelime hazinesinin geliştirilmesi temasıdır. Tema ile ilgili olarak görüşme yapılan öğretim üyelerinin görüşleri şunlardır:

"Dil ve düşünce birbirini etkilemekte. Bireyin anadilini ne kadar iyi kullanırsa o kadar iyi düşünüleceği savunuluyor. Kelime hazinesinin çok olması bu açıdan önemli. Çocuk ne kadar fazla kelime bilirse o kadar iyi düşünmekte" (Ögretim Üyesi 4). "Öğrencinin kelime bilgisi ne kadar fazla ise, okuduğunu o kadar iyi anlamakta.” (Öğretim Üyesi 6).

Öğretim üyelerinin görüşleri incelendiğinde, kelime hazinesi konusunun düşünce ve okuduğunu anlama konularıyla ilişkilendirildiği görülmektedir.

\section{Okuma Yazma Sevgi ve Alışkanlığg}

Dünya'da ve Türkiye'de anadili eğitimine yönelik tespit edilen beşinci güncel yönelim okuma yazma sevgi ve alışkanlığı temasıdır. Tema ile ilgili olarak görüşme yapılan öğretim üyelerinin görüşleri şunlardır:

"Ilkokulda okuma sevgisi ve alışkanlı̆̆l kazandırllmalı çocuğa. Bunlar kazanıldığ zaman çocuk kendi kendine gelişiyor. Çocuğun zekâsı gelişiyor.” (Öğretim Üyesi 4). "Okuma özellikle sinavlarda çok önemli. Kitap okuma alışkanlığl olan çocuklar paragraf sorularında sıkılmıyorlar. Okuma alışkanlığl olmayanlar sıkılıyorlar." (Ögretim Üyesi 5).

Öğretim üyelerinin görüşleri incelendiğinde, okuma yazma sevgi ve alışkanlığının öneminin vurgulandığ görülmektedir.

\section{Medya Okuryazarlığg}

Dünya'da ve Türkiye'de anadili eğitimine yönelik tespit edilen ikinci güncel yönelim medya okuryazarlığı temasıdır. Tema ile ilgili olarak görüşme yapılan öğretim üyelerinin görüşleri şunlardır:

"Dil öğretiminde medyanın etkisi çoğaldı. Televizyon izleyerek çocukların anadili gelişiminde artış olduğuna inanıyorum. Tabi televizyonun olumsuz etkileri de var çocuk üzerinde." (Ö̆gretim Üyesi 6). "Televizyon izleme çocuğun kelime hazinesini geliştiriyor.” (Öğretim Üyesi 4).

Öğretim üyelerinin görüşleri incelendiğinde, televizyonun anadili üzerindeki olumlu etkileri üzerinde durulduğu dikkat çekmektedir.

\section{Eleștirel Okuma}

Dünya'da ve Türkiye'de anadili eğitimine yönelik tespit edilen yedinci güncel yönelim eleştirel okuma temasıdır. Tema ile ilgili olarak görüşme yapılan öğretim üyesinin görüşleri şunlardır:
"Cocukların okuduklarına hemen inanmamaları gerekli. Aynı bilgiye birkaç farklı bakış açısıyla bakabilmeli. Farklı kaynaklardan okuyarak, en sonunda kendi karar vermeli." (Ö̈̆retim Üyesi 2).

Öğretim üyesinin görüşü incelendiğinde, anadili eğitiminde çocuğun okuduklarına eleştirel olarak yaklaşması vurgulanmaktadır.

\section{Millî Kültür}

Dünya'da ve Türkiye'de anadili eğitimine yönelik tespit edilen sekizinci güncel yönelim milli kültür temasıdır. Tema ile ilgili olarak görüşme yapılan öğretim üyesinin görüşleri şunlardır:

“Tüm anadili ögretim programlarında millî kültür konusuna değinilmekte. Ayrlca anadili milleti oluşturan unsurlardan birisi. Toplumdaki insanlar arasında iletişimi sağlayan anadilidir." (Öğretim Üyesi 7).

Öğretim üyesinin görüşleri incelendiğinde, milli kültürü oluşturan anadiline vurgu yapıldığı görülmektedir.

\section{Kalem Yerine Klavye Kullanımı}

Dünya'da ve Türkiye'de anadili eğitimine yönelik tespit edilen dokuzuncu güncel yönelim kalem yerine klavye kullanımı temasıdır. Tema ile ilgili olarak görüşme yapılan öğretim üyesinin görüşleri şunlardır:

“Gelişmiş dünya ülkelerinde kalem kullanmayıp, klavyeyle yazma öğretimine yönelik bir ĕgilim var. Fakat ben kalemin terk edilmesine karşıyım. Kalem kullanımının öğrenciye çok faydalarının olduğunu düşünüyorum." (Öğretim Üyesi 5).

Öğretim üyesinin görüşü incelendiğinde, gelişmiş dünya ülkelerinde kalem yerine klavye kullanımına yönelik eğilim olduğu anlaşılmaktadır. Ancak öğretim üyesinin bu duruma karşı çıktığ 1 görülmektedir.

\section{Metinler Arası Okuma}

Dünya'da ve Türkiye'de anadili eğitimine yönelik tespit edilen onuncu güncel yönelim metinler arası okuma temasıdır. Tema ile ilgili olarak görüşme yapılan öğretim üyelerinin görüşleri şunlardır:

"Metinler arası okuma ülkemizde önem kazanmaya başladı. Türkçe dersi öğretim programlarında bunu görmekteyiz." (Ögretim Üyesi 2). "Özellikle Amerika ve Ingiltere'de metinler arası okumaya ăgırlık verilmekte.” (Öğretim Üyesi $5)$.

Öğretim üyelerinin görüşleri incelendiğinde, metinler arası okumanın gelişmiş dünya ülkelerinde ve ülkemizde ağırlık kazandığı görülmektedir.

\section{1. Üst Düzey Bilişsel Becerileri Geliştirme}

Dünya'da ve Türkiye'de anadili eğitimine yönelik tespit edilen on birinci güncel yönelim üst düzey bilişsel becerileri geliştirme temasıdır. Tema ile ilgili olarak görüşme yapılan öğretim üyesinin görüşleri şunlardır:

"Anadili öğretimi aynı zamanda düşünmeyi de geliştirmektedir. Zaten üst düzey bilişsel becerileri yerine getirirken çocuğun anadilini kullanması gerekli. Bu açıdan anadili eğitimi üst düzey becerileri de geliştirmekte" (Ö̈̆retim Üyesi 7). 
Öğretim üyesinin görüşleri incelendiğinde, anadili ile düşünme becerisi arasındaki ilişkiye değinildiği görülmektedir.

\section{Görsel Okuryazarlık}

Dünya'da ve Türkiye'de anadili eğitimine yönelik tespit edilen on ikinci güncel yönelim görsel okuryazarlık temasıdır. Tema ile ilgili olarak görüşme yapılan öğretim üyesinin görüşleri şunlardır:

“Günümüzde görsel okuma gerektiren uyaranlar oldukça fazla. Tabelalar, reklamlar, trafik işaretleri, grafikler, tablolar. Öğrencinin bunlarl anlayabilmesi gerekli. Bu nedenle görsel okuma önemli." (Ögretim Üyesi 6).

Öğretim üyesinin görüşleri incelendiğinde, görsel okuryazarlığın öneminin vurgulandığı anlaşılmaktadır.

\section{Günlük Hayatla İlişkilendirme}

Dünya'da ve Türkiye'de anadili eğitimine yönelik tespit edilen on üçüncü güncel yönelim günlük hayatla ilişkilendirme temasıdır. Tema ile ilgili olarak görüşme yapılan öğretim üyelerinin görüşleri şunlardır:

“Çift dil, Illinois'de çok popüler hale geliyor ve belli bir süreden sonra anadili saf dişı birakmak için tasarlanan iki dilli programları değiştiriyor. Sonuçlar etkileyici. Ancak, bu programlarl finanse etmek zordur ve eğitimli ögretmenler bulmak da çok zor olabilir. İspanyolca, bu dillerin en göze çarpan kismidir, ancak Kantonca, Urduca, Lehçe ve diğer dillerdeki diğer ikili dil programlarımız da var. Ama pahalı olabilecek çok fazla enerji, gözetim ve malzeme gerektiriyor.” (Öğretim Üyesi 1). “Öğrenci, hocam hayatta ne işime yarayacak diyor. Hayatla ilişkilendirdiğiniz zaman öğrenci daha iyi öğreniyor. Örneğin dilekçe yazma işine yaradı̆̆ için daha dikkatli dinliyor." (Öğretim Üyesi 5).

Öğretim üyelerinin görüşleri incelendiğinde, çift dillilik konusunun ağırlık kazanmaya başladığı görülmektedir. Ayrıca, günlük hayatta kullanım konusunun üzerinde durulmaktadır.

\section{Süreç Değerlendirme}

Dünya'da ve Türkiye'de anadili eğitimine yönelik tespit edilen on dördüncü ve son güncel yönelim süreç değerlendirme temasıdır. Tema ile ilgili olarak görüşme yapılan öğretim üyesinin görüşleri şunlardır:

“Artık test türü sınavlara soğuk bakılıyor Türkçe eğitiminde. Ağırlıklı olarak süreç değerlendirme belirtiliyor. Ancak çocuk büyük sınavlarda test türü sinavlarla ölçülüyor." (Öğretim Üyesi 7).

Öğretim üyesinin görüşleri incelendiğinde, ana dili eğitiminde test türü sınava ilişkin olumsuz tutumlar dikkat çekmektedir.

\section{Sonuç ve Öneriler}

Dünya'da ve Türkiye'de anadili eğitiminde güncel yönelimlerin öğretim üyelerinin görüşleri doğrultusunda değerlendirildiği bu araştırma neticesinde on dört adet temaya ulaşılmıştır. Ulaşılan bu temalar şunlardır: Akıcı okuma ve konuşma, teknoloji kullanımı, okuma yazma öğretimine seslerle başlama, kelime hazinesinin geliştirilmesi, okuma yazma sevgi ve alışkanlığı, medya okuryazarlığı, eleştirel okuma, millî kültür, kalem yerine klavye kullanımı, metinler arası okuma, üst düzey bilişsel becerileri geliştirme, görsel okuryazarlık, günlük hayatla ilişkilendirme, süreç değerlendirme.

Anadili eğitiminde akıcı konuşma ve okuma önemli eğilimlerden biridir. Akıcı okuma ile öğrencinin okuduğunu daha iyi anlaması hedeflenmektedir. Akıcı konuşma ile de bireyin toplumdaki iletişiminin daha iyi olması amaçlanmaktadır. İngiltere'deki anadili öğretim programında, İngilizcede yüksek kalitede bir eğitimin, öğrencilere akıcı bir şekilde konuşma, okuma ve yazma öğretilerek gerçekleştirilebileceği vurgulanmaktadır. Ayrıca aynı programda, İngiltere'de toplumun bir üyesi olabilmek için, haklardan mahrum olmamak için akıcı ve güvenli bir şekilde konuşma ve yazmanın gerekli olduğu belirtilmektedir (İngiltere Ulusal Eğitim Programı, 2014: 3). Türkiye'de Türkçe Dersi Öğretim Programında ölçme ve değerlendirme sürecinde kontrol listesi, dereceli puanlama anahtarı ve değerlendirme ölçeği şeklinde yapılandırılmış gözlem formlarından yararlanılması gerektiği belirtilmektedir. $\mathrm{Bu}$ formlarda akıcı okuma becerilerinin gözlemlenmesine imkân sağlayan ölçütlere yer verilmesi gerektiği vurgulanmaktadır (MEB, 2018a: 9). Öğretmenlerin öğrencilerin akıcı okuma becerilerini geliştirme çalışmaları yürütmesi gerektiği dile getirilmektedir. Öğrencilerin dil gelişiminde akıcılığı geliştirmeye yönelik olarak tekerlemelerin ilk okuma yazma öğretiminde kullanılması önerilmektedir (MEB, 2018a: 15). Günümüzde hızlı okuma kavramının yerini akıcı okuma kavramının aldığı düşünülmektedir.

Anadili eğitiminde teknoloji kullanımının hızla arttığı sonucuna ulaşılmıştır. Türkiye'de özellikle Fatih projesiyle bu durum görülmektedir. Tüm sınıflarda akıllı tahtanın yer almasıyla birlikte anadili eğitiminde de akıllı tahta kullanımında doğal olarak artış görülmüştür. Türkçe Dersi Öğretim Programında teknolojik unsurların sıklikla kullanılması gerektiği belirtilmektedir (MEB, 2018a: 9). Eaton (2010: 14) anadili öğretiminde teknoloji kullanımının tüm dünyada hızlı bir şekilde artış gösterdiğini belirtmektedir. Amerika Birleşik Devletleri Ortak Temel Standartlarda (2010: 22) bilgilerin ifade edilmesi ve sunumların anlaşılmasını geliştirmek için teknolojinin stratejik kullanılması gerektiği vurgulanmaktadır. Türkiye'de Türkçe Dersi Öğretim Programında öğrenme öğretme sürecinde mümkün olduğunca bilgi ve iletişim teknolojilerinden yararlanılması gerektiği belirtilmektedir. $\mathrm{Bu}$ teknolojilerin kullanılması öğretim stratejilerini zenginleştirdiği, aynı zamanda öğrencilerin öğrenmelerini desteklediği vurgulanmaktadır. Öğrencilerin veri toplama, organize etme ve sınıflamada, bulguları yazma, düzenleme ve sunma aşamalarında bilgisayar programlarından yararlanmaları için teşvik edilmesi gerektiği dile getirilmektedir. Dersin işlenişinde ve uygulamalarda görsel iletişim araçlarına yer verilmesi gerekmektedir. Slayt, bilgisayar, televizyon, etkileşimli tahta, internet, EBA içeriklerinin etkin olarak kullanılması gerekmektedir (MEB, 2018a: 9). Türkiye'de Fatih Projesi kapsamında yapılanların, anadili eğitiminde daha fazla teknoloji kullanımına neden olduğu düşünülmektedir.

Türkiye'de 2005 yılından bu yana okuma ve yazma öğretiminde ses yöntemi kullanılmaktadır. Gelişmiş çoğu dünya ülkesinde de okuma öğretimine seslerle başlandığı tespit edilmiştir. Amerika Birleşik Devletleri Ortak Temel 
Standartlarına (2010: 15) göre okuma öğretiminde öncelikle sesli fonemler (a, e, i, o) tanıtılmaktadır. Her bir sesli fonemin ardından sesin harfi öğretilmektedir. Ardından sessiz fonemler tanıtılmaktadır. Her bir sessiz fonemin öğretilmesinin ardından harfi öğretilmektedir. Günümüzde Amerika, İngiltere, İrlanda, Hindistan, Finlandiya, Lübnan, İsviçre, İran, Portekiz, Lüksemburg, İtalya'da okuma yazma öğretimine harflerin seslerinin tanıtılmasıyla başlanmaktadır (Güneş, 2007: 169). Türkiye'de Türkçe Dersi Öğretim Programına göre "Ses Esaslı İlk Okuma Yazma Öğretimi" benimsenmiştir (MEB, 2018a: 10). Ses esaslı ilk okuma yazma öğretiminde şu sıralama ile okuma yazma öğretimi gerçekleştirilmektedir: 1 . Sesi hissetme, tanıma ve ayırt etme 2. Harfi okuma ve yazma 3. Harflerden heceler, hecelerden kelimeler, kelimelerden cümleler oluşturma 4. Metin okuma.

Gelişmiş dünya ülkelerinin anadili öğretiminde ve Türkiye'de kelime hazinesi üzerinde durulan bir konudur. Tüm eğitim seviyelerinde öğrenciler bilmedikleri kelimelerle karşılaşmaktadırlar. Her öğrenilen yeni kelime öğrencinin kelime dağarcığını geliştirmektedir. İngiltere Ulusal Eğitim Programı (2014: 3), öğrencilere geniş bir kelime dağarcığı kazandırılmasının önemini vurgulamaktadır. Türkçe Dersi Öğretim Programı ile öğrencilerin; okuduğundan, dinlediğinden/izlediğinden hareketle, söz varlığını zenginleştirerek dil zevki ve bilincine ulaşmaları vurgulanmaktadır. Öğrencilerin duygu, düşünce ve hayal dünyalarını geliştirmelerinin sağlanması amaçlanmaktadır (MEB, 2018a: 8). Kelime hazinesinin zenginliğinin düşünme becerisine olan katkısı bilinmektedir. $\mathrm{Bu}$ nedenle, kelime hazinesini geliştirmeye yönelik eğilimlerin yerinde olduğu düşünülmektedir.

Bireylere okuma sevgi ve alışkanlığının kazandırılması anadili eğitiminin önemli hedefleri arasında yer almaktadır. İngiltere Ulusal Eğitim Programına (2014: 3) göre, öğrencilerde zevk için yaygın okuma yoluyla yüksek dil ve okuryazarlık standartlarını teşvik etmek gerekmektedir. Hem zevk hem de bilgi için yaygın ve sık okuma alışkanlığının geliştirilmesi amaçlanmaktadır. İngiltere'de anadili öğretim programına göre temel amaç, öğrencilere keyifle yapılan okumalarla öğrencilerin edebiyat sevgisini arttırmaktır (Yaman ve Demirtaş, 2013: 6). Türkçe Dersi Öğretim Programında, öğrencilerin istek duyarak okuma ve yazma alışkanlığı edinmelerini sağlayacak şekilde bilgi, beceri ve değerleri içeren bir bütünlük içinde yapılandırıldığı belirtilmektedir. Yine aynı programa göre öğrencilerin; okuma yazma sevgisi ve alışkanlığını kazanmalarının sağlanması amaçlanmaktadır (MEB, 2018a: 8). Türkiye'de Türk dili ve edebiyatı programıyla öğrencilerin okuma alışkanlığı kazanmaları amaçlanmaktadır (MEB, 2018b: 12). Okuma, yazma sevgi ve alışkanlığı bulunan bireylerin hem akademik hayatında hem de günlük yaşamında bir adım önde olduğu bilinmektedir. Ancak okuma yazma sevgi ve alışkanlığının günümüzdeki en büyük düşmanı olarak teknolojik aletler ve sosyal ağlar gelmektedir.

Anadili eğitimdeki yeni yönelimlerden birisi de medya okuryazarlığıdır. Medyanın doğru bir şekilde okunması gerektiğine özellikle vurgu yapılmaktadır. Amerika Ortak Temel Standartlarına (2010: 4) göre yaşama hazır olmak için eski ve yeni medya formlarında metinleri analiz etme ve oluşturma vurgulanmaktadır. Medya üretme ve tüketme ihtiyac1, günümüz müfredatının her yönüne yerleştirilmektedir. Medya becerileri ve anlayışları, ayrı bir bölümde ele alınmak yerine Amerika Ortak Temel Standartlarının tüm bölümlerinde yer almaktadır. Öğrencilerin çeşitli medya ve formatlarda sunulan bilgileri bütünleştirmesi ve değerlendirmesi gerektiği vurgulanmaktadır (Amerika Ortak Temel Standartlar, 2010: 22). Türkçe Dersi Öğretim Programı ile öğrencilerin; basılı materyaller ile çoklu medya kaynaklarından bilgiye erişme, bilgiyi düzenleme, sorgulama, kullanma ve üretme becerilerinin geliştirilmesi amaçlanmaktadır (MEB, 2018a: 8). Türk dili ve edebiyatı dersi öğretim programı ile lise öğrencilerine medya okuryazarlığının kazandırılması amaçlanmaktadır (MEB, 2018b: 12). Medyayı doğru takip etmek, bireyin düşünce süzgecinden geçirmesi önem arz ettiği düşünülmektedir.

Eleştirel okuma anadili eğitimindeki yönelimlerden bir başkasıdır. Öğrencilerin okumalarında eleştirel davranmalarını, okudukları hakkında sorgulayıcı olmaları vurgulanmaktadır. ABD New York Eyaleti'nde anadili öğretim programı, İngilizceyi öğrenenlerde eleştirel okuryazarlık becerilerinin geliştirmesini amaçlamaktadır (Yaman ve Demirtaş, 2013: 5). Türkçe Dersi Öğretim Programı ile öğrencilerin okuduklarını anlayarak eleştirel bir bakış açısıyla değerlendirmelerinin ve sorgulamalarının sağlanması amaçlanmaktadır (MEB, 2018a: 8). Türk dili ve edebiyatı programıla öğrencilerin metinler aracılığıyla okuduğunu anlama ve eleştirel okuma becerilerini geliştirmeleri ve okuma alışkanlığı kazanmaları amaçlanmaktadır. Yine aynı program ile öğrencilerin eleştirel düşünme becerilerinin geliştirilmesi öngörülmektedir (MEB, 2018b: 12). Anadili eğitimindeki eleştirel okuma yönelimi dikkat çekmektedir. Bireylerin okuduklarına hemen inanmak yerine, eleştirel olarak yaklaşmaları önemlidir.

Anadili eğitimindeki yönelimlerden bir diğeri millî kültür konusudur. Danimarka'da anadili öğretim programının amacı; öğrencileri dil anlayışı ile edebiyat, kişisel ve kültürel kimlik gelişimi, kendini ifade konularında teşvik etmektir. Ayrıca anadili öğretimi ortak İskandinav kültürünün edinilmesini amaçlamaktadır. Fransa'da anadili öğretim programı, özellikle "Fransız diline hâkimiyete" dayanmaktadır. Fransa anadili öğretim programı insancıl bir kültür edinilmesine katkı sağlamaktadır. Çek dili ve edebiyatı anadili öğretim programı öğrencilerin dili sözlü veya yazılı bir şekilde kullanarak toplumla kaynaşmasına ve toplumdaki sosyal kültürel gelişmeleri takip etmelerine olanak sağlamaktadır. Program dili, toplumun birleştirici ana unsuru olarak görmektedir. Avustralya'da İngilizce öğretim programı, ögrencilerin kendi toplumsal yapısının farkında olan, kendi kültür değerleriyle barışık, yerelliklere saygılı olmayı amaçlamaktadır (Yaman ve Demirtaş, 2013: 5). Türkçe Dersi Öğretim Programı, öğrencilerin Türkçe sevgisiyle yetiştirilmesi amaçlanmaktadır. Yine aynı program ile öğrencilerin; millî, manevi, ahlaki, tarihî, kültürel, sosyal değerlere önem vermelerinin sağlanması, millî duygu ve düşüncelerinin güçlendirilmesi, Türk ve dünya kültür ve sanatına ait eserler aracılığıyla estetik ve sanatsal değerleri fark etmelerinin ve benimsemelerinin sağlanması amaçlanmaktadır (MEB, 2018a: 8). Türk Dili ve Edebiyatı Programıla öğrencilerin edebî metinler aracılığıyla Türkçenin inceliklerini, Türk edebiyatının tarih içinde gösterdiği değişim ve gelişimi tanımaları, Türk edebiyatına ait eserler aracılığıyla millî, manevi, ahlaki, kültürel ve evrensel değerleri anlamaları amaçlanmaktadır 
(MEB, 2018b: 12). Türkiye'de özellikle hain 15 Temmuz darbe girişiminden sonra anadili programlarımızda milli değerlerimizin daha fazla yer almaya başladığı görülmektedir.

Anadili eğitiminde görülen bir başka yönelim kalem yerine klavye kullanılması eğilimidir. Kalem yerine klavyeyle yazma Kanada, Amerika Birleşik Devletleri ve Finlandiya'da gündeme gelmiştir. Kanada Kebek'te 2001 yılında yazma öğretimine tuşlarla başlanmıştır. Amerika Birleşik Devletlerinde 2014 y1lında 45 eyalette eğitimde tablet kullanımına geçilerek kalemle yazma öğretimi azaltılmıştır. Finlandiya'da ise 2016 y1lından itibaren kalem bir kenara bırakılarak tablet bilgisayarlarla okuma yazma öğretilmesi için hazırlıklar yapılmıştır (Güneş, 2016: 21). Türkiye'de halen kalemle yazma öğretimine devam edilmektedir. Ancak Fatih Projesi kapsamında lise öğrencilerine ücretsiz olarak dağıtılan tablet bilgisayarların kullanımı, öğrencilerin kalem kullanmalarında azalmaya neden olmuştur.

Anadili eğitimindeki bir diğer yönelim metinler arası okuma kavramıdır. Amerika Birleşik Devletleri Michigan Eyaletinde ilköğretim birinci sınıf ilk okuma yazma öğretim programında, metindeki fikirler arasında bağlantı kurarak metin içi ve metinler arası bağlantılar ve karşılaştırmalar yaparak bunları sözlü ve yazılı cevaplarda kullanma vurgulanmaktadır (Bay, 2014: 291). Türkçe Dersi Öğretim Programına göre, tematik yaklaşım esas alınarak hazırlanan öğretim programında okuma ve yazma kazanımları metin içi, metin dışı ve metinler arası okuma yoluyla anlam oluşturmayı sağlayacak şekilde yapılandırılmıştır (MEB, 2018a: 8). Metinler arası okuma kavramı özellikle Türkiye'de son yıllarda önemini artırmaya başlamıştır.

Anadili eğitimindeki bir başka yönelim üst düzey bilişsel becerilerin geliştirilmesidir. Anadili eğitimiyle öğrencilerin üst düzey bilişsel becerilerinin geliştirilmesi amaçlanmaktadır. Bu durum dil ile düşünce arasındaki ilişkiyi akla getirmektedir. Avustralya İngilizce öğretim programı, dünyayla bütünleşmiş, düşünen, araştıran, sorgulayan, üreten bireyler yetiştirmek amacıyla hazırlanmış bir programdır (Yaman ve Demirtaş, 2013: 5). Amerika Ortak Temel Standartlarına (2010: 4) göre, öğrencilerin bilgi ve fikirleri toplama, anlama, değerlendirme, sentez yapma, rapor hazırlama, sorulara cevap vermek veya problemleri çözmek için özgün araştırmalar yapma becerisine sahip olmaları vurgulanmaktadır. Türkçe Dersi Öğretim Programında öğrencilerin zihinsel becerileri kazanmaları amaçlanmaktadır. Programda tüm sınıf seviyelerinde kazanımların yapısının ve hiyerarşisinin, öğrencilerin üst düzey bilişsel becerilerini geliştirmelerine katkı sağlayacak şekilde düzenlendiği vurgulanmaktadır. Türkçe Dersi Öğretim Programı ile öğrencilerin; bilgiyi araştırma, keşfetme, yorumlama, zihinde yapılandırma becerilerinin geliştirilmesi amaçlanmaktadır (MEB, 2018a: 8). Türkçe Dersi Öğretim Programına göre yazılı sınavlar hazırlanırken öğrencilerin üst düzey bilişsel becerilerin kullanılmasına imkân sağlayan çeşitli madde türlerinden yararlanılması gerektiği belirtilmektedir. $\mathrm{Bu}$ tarz maddelerin öğrencilerin çıkarımda bulunma, eleştirel düşünme, analiz etme, görsel okuma, akıl yürütme, uzamsal becerilerini kullanmaları ve geliştirmelerine katkı sağladığı vurgulanmaktadır (MEB, 2018a: 9-10). Türkçe Dersi Öğretim Programına göre anlama, sıralama, sınıflama, sorgulama, ilişki kurma, analiz sentez yapma ve değerlendirme gibi zihinsel becerilerin geliştirilmesinde ilk okuma yazma öğretiminin önemli bir işlevi bulunmaktadır (MEB, 2018a: 10). Türk dili ve edebiyatı dersi öğretim programı öğrencilerin; çeşitli kaynaklardan elde ettikleri bilgileri, soruları cevaplamak, çözüm önerileri üretmek, bulgularını paylaşmak gibi amaçlar için analiz etmeleri ve değerlendirmeleri amaçlanmaktadır (MEB, 2018b: 12). Anadili eğitiminin aynı zamanda düşünmeyi geliştirmesinden hareketle, üst düzey bilişsel becerilere daha fazla vurgu yapıldığı düşünülmektedir.

Anadili eğitimindeki bir diğer yönelim görsel okuryazarlık kavramıdır. Görsel unsurların hızla arttığı günümüzde, görsel okuryazarlık konusu anadili eğitiminde yerini almıştır. Amerika Birleşik Devletleri Michigan Eyaletinde ilköğretim birinci sınıflarında kullanılan ilk okuma yazma öğretim programında, hikâye edici metinde (anadili, kendine özgü hareket ve duygu) ve bilgilendirici metinde (ardışık, özel kelime, görsel sunum) sözlü, yazılı ve görsel mesajları iletmede kişisel tarz oluşturma amaçlanmaktadır (Bay, 2014: 293). Türkçe Dersi Öğretim Programına göre dersin işlenişinde ve uygulamalarda görsel iletişim araçlarına yer verilmelidir. Slayt, bilgisayar, televizyon, etkileşimli tahta, internet, EBA içerikleri etkin olarak kullanılmalıdır. Ölçme ve değerlendirme aşamasında hazırlanan maddeler, mümkün olduğunca yazılı (kısa metin, şiir, tablo, grafik vb.) ve görsel unsurlar (karikatür, fotoğraf, resim vb.), grafik düzenleyiciler (kavram haritaları, zihin haritaları vb.) gibi öncüllere yer verilerek zenginleştirilmelidir. Bunların aktif kullanımları gerekmektedir (MEB, 2018a: 9-10). Türk dili ve edebiyatı dersi öğretim programı ile öğrencilere görsel okuryazarlık becerisinin kazandırılması amaçlanmaktadır (MEB, 2018b: 12). Günümüzdeki tablo, grafik, tabela, afiş gibi görsel unsurların artmasından dolayı, görsel okuryazarlık kavramının anadili eğitiminde daha fazla yer aldığı görülmektedir.

Anadili eğitimindeki bir başka yönelim günlük hayatla ilişkilendirme konusudur. Dil laboratuvarlarının amacı, öğrencilere çalıştıkları dile işitsel aşinalık kazandırmaktı. $\mathrm{Bu}$, öğrencilere dili dinleme firsatını sunduğu için, orta yüzyılda önemli bir yenilik olarak kabul edildi. O sırada öğrenciler seyahat etmek için daha az fursat sahibiydi. İnternet diye bir şey yoktu. Günümüzün dijital dünyasında, dillere sese maruz kalmak, çok az maliyetle ve ücretsiz olarak mevcuttur. Uydu radyo, internet radyosu bulunmaktadır. Yirmi birinci yüzyılda, dil laboratuvarları oluşturmak, okulun sınırlı para, zaman ve diğer kaynaklarının akıllıca bir kullanımı değildir (Eaton, 2010: 10). Çek dili ve edebiyatı programı öğrencilerin dili sözlü ya da yazılı bir şekilde kullanarak toplumla kaynaşmasına ve toplumdaki sosyal kültürel gelişmeleri takip etmelerine olanak sağladığını belirtmektedir. Finlandiya'da anadili ve edebiyat öğretim programına göre öğretim, toplum odaklı bir görünümü esas almaktadır. Toplumun bir parçası hâline gelme ve topluma katılım (bağlılık) kişinin içinde bulunduğu toplumun dilini öğrenmesiyle başlamaktadır. Almanca öğretim programına göre öğrencilerin Almanca öğrenmelerindeki temel amaç; doğru iletişim kurabilmesi, dilin anlatım imkânlarını kullanabilmesi amaçlanmaktadır. Avustralya'da İngilizce öğretim programı, Avustralya'nın geleceğinde sorumluluk sahibi bireyler yetiştirmek amacıyla hazırlanmış bir programdır. ABD New York Eyaleti'nde programda, sosyal etkileşim için okuma, yazma, dinleme ve konuşma becerilerinin geliştirilmesi vurgulanmaktadır 
(Yaman ve Demirtaş, 2013: 5, 6). Türkçe Dersi Öğretim Programına göre öğrencilerin öğrendiklerini içinde yaşadıkları sosyokültürel ve çevresel durumlarla ilişkilendirmelerine imkân sağlayan, aktif olarak katılabileceği etkinlik ve çalışmalara yer verilmelidir. $\mathrm{Bu}$ tarz etkinlik ve çalışmalar öğrenmeyi daha anlamlı ve kalıcı kılmaktadır. Öğrencilerin öğrenmeye karşı olumlu tutum geliştirmelerine katkı sağladığı belirtilmektedir (MEB, 2018a: 8-9). Öğrencinin anadilini günlük yaşamında aktif olarak kullandığı bir gerçektir. Buradan hareketle, anadili eğitiminde günlük kulanım unsurlarının yer alması önemli ve faydalı bulunmaktadır.

Anadili eğitiminde son olarak tespit edilen yönelim süreç değerlendirme konusudur. Bir öğrenci portföyü, somut yollarla başarıyı göstermektedir. Aynı zamanda öğrencilerin öğrenmeyi süreç temelli bir yaklaşımla değerlendirmek için bir araçtır. Süreç değerlendirme; geleneksel, açık temelli değerlendirme modellerinin yerini almaktadır. Bugün dil edinimi karmaşı, doğrusal olmayan ve iletişimsel bir çaba olarak görülmektedir. Geleneksel veya boşluğu dolduran faaliyetler ve testler, bir dili öğrenme ile ilgili net bilgiler vermemektedir. Son yirmi yılda, süreç değerlendirmenin geliştirilmesi ve uygulanmasına yönelik dünya çapında bir hareket olmuştur (Eaton, 2010: 12). Türkçe Dersi Öğretim Programına göre öğrencilere kazandırılması hedeflenen bilgi ve becerilerin ne oranda gerçekleştiğinin tespitinde kullanılan ölçme ve değerlendirme uygulamaları sürekli olmalıdır. Öğrenme öğretme sürecinin ayrılmaz bir parçası olan ölçme ve değerlendirme uygulamalarında özellikle birinci, ikinci ve üçüncü sınıflarda süreç ve performans temelli bir yaklaşım benimsenmelidir. Dil becerilerinin ayrı veya bütüncül olarak değerlendirilebilmesi için eğitim öğretim yılı sürecinde öğrenci ürün dosyaları ile elektronik portfolyolardan da yararlanılması gerektiği belirtilmektedir (MEB, 2018a: 9-10). Anadili gelişimi süreklilik göstermektedir. $\mathrm{Bu}$ nedenle süreç değerlendirmeye vurgu yapılması önem arz etmektedir.

Ülkelerin anadili öğretim programları milletin ve devletin amaçları doğrultusunda şekillenmektedir. Geçmişte ülkeler asırlardır geleneksel olarak edebiyat ve edebiyat tarihi öğretimini, sıkı dil bilgisi öğretimini merkeze alarak ana dillerini öğretmeye çalışmışlardır. Ancak günümüzde bu yaklaşımlar güncelliğini kaybetmiştir. Artık anadili öğretimi, günlük yaşamda bireylerin anlama ve anlatma becerilerini geliştirmeyi, ayn zamanda anadilini doğru ve düzgün kullanabilmeyi, edebi bir zevk ve estetik duygusu kazanmayı amaçlamaktadır. Bunun yanı sıra anadili öğretimi, bireylerin metinler ile kültürel ve evrensel değerleri benimsemelerini mümkün kılmaktadır (Yaman ve Demirtaş, 2013: 4-5).

Araştırma sonuçları kapsamında şu önerilerde bulunulmuştur:

(i) Türkiye'de akıcı okuma konusu üzerinde durulmaktadır. Ancak akıcı konuşma konusunun göz ard1 edildiği tespit edilmiştir. $\mathrm{Bu}$ nedenle Türkiye'deki anadili öğretim programında akıcı konuşma konusuna daha fazla ağılık verilmesi önerilmektedir. Bu konuda, öğrencilere hazırlıksız konuşma çalışmaları, hazırlıkı konuşma etkinlikleri, tiyatroda rol alma, sesli şiir okuma, sesli okuma görevlerinin faydalı olacağı düşünülmektedir. (ii) Türkiye'de Fatih Projesi kapsamında lise öğrencilerine ücretsiz olarak tablet dağıtılmıştır. $\mathrm{Bu}$ uygulamanın anadili eğitimi kapsamında, ilkokul ve ortaokul öğrencilerine de yapılması önerilmektedir. $\mathrm{Bu}$ şekilde, anadili eğitiminde teknoloji kullanım imkânı artırılmış olacaktır.

(iii) Türkiye'de Fatih Projesi kapsamında sınıflara akıllı tahta yerleştirilmiştir. Ancak halen akıllı tahta olmayan sınıflar bulunmaktadır. Anadili eğitimi bakımından, akıllı tahtası olmayan sinıflara akıllı tahta takılması önerilmektedir.

(iv) Türkiye'de kalem yerine klavyeyle yazma öğretimi konusunun tartışılması ve araştırılması önerilmektedir.

(v) Yapılan bu araştırmada Çin, Japonya gibi ülkelerin anadili öğretim programları incelenememiştir. Yapılacak araştırmalarla belirtilen ülkelerin anadili öğretim programları çalışılabilir.

\section{Kaynakça}

Amerika Ortak Temel Standartlar (2010). Common core state standards for english language arts \& literacy in history/social studies, science, and technical subjects. Common Core State Standards Initiative.

Ata, A. (2004). Dil. Türk dili (2. Baskı), (Editör: Hülya Pilanc1). Eskişehir: Anadolu Üniversitesi Yayını.

Batur, Z. (2010). Ana dili öğretiminde gösterge biliminin yeri: ana dili ders kitaplarındaki sözel metinlerle görsel metinleri bütünselliğinin analizi. Turkish Studies International Periodical For the Languages, Literature and History of Turkish or Turkic, 5(4), 174-200.

Bay, Y. (2014). Amerika Birleşik Devletleri Michigan Eyaletinde ilköğretim birinci sınıflarında kullanılan ilk okuma yazma öğretim programlarının incelenmesi. Uşak Üniversitesi Sosyal Bilimler Dergisi, 7(3), 281-298.

Braun, V., \& Clarke V. (2006). Using thematic analysis in psychology. Qualitative Research in Psychology, 3(2), 77-101.

Christensen, L. B., Johnson, R. B., \& Turner, L. A. (2015). Araştırma yöntemleri desen ve analiz (Çev. Edt: Ahmet Aypay). Anı Yayıncilık. Ankara.

Çelebi, M. D. (2006). Türkiye'de anadili eğitimi ve yabancı dil öğretimi. Sosyal Bilimler Enstitüsü Dergisi, 21, 285307.

Dean, J. (2005). A teaching assistant's guide to primary education. Oxon: Routledge.

Demir, C., \& Yapıcı, M. (2007). Ana dili olarak Türkçenin öğretimi ve sorunları. Sosyal Bilimler Dergisi, 9(2), 177192.

Demirezen, M. (2003). Yabanci dil ve anadil öğreniminde kritik dönemler. TÖMER Dil Dergisi, 118, 5-15.

Eaton, S.E. (2010). Global trends in language learning in the twenty-first century. Calgary: Onate Press.

Eker, S. (2015). Dil ve kültür. Türk dili-I (Editörler: Prof.Dr. Muhsin Macit ve Yrd.Doç.Dr. Serap Cavkaytar). Eskişehir: Anadolu Üniversitesi Yayını. 
Gliner, J. A., Morgan, G. A., \& Leech, N. L. (2015). Uygulamada araştırma yöntemleri: desen ve analizi bütünleştiren yaklaşım. (Çev. Ed.: Selahattin Turan). Ankara: Nobel Yayın Dağıtım.

Güneş, F. (2007). Ses temelli cümle yöntemi ve zihinsel yapılandırma. Ankara: Nobel Yayın Dağıtım.

Güneş, F. (2016). Eğitimde kalem ve tuşlarla yazma tartışmaları. Bartın Üniversitesi Ĕgitim Fakültesi Dergisi, 5(1), 19-33.

Hamzadayı, E. (2010). Yapılandırılmış öğrenme kuramının anadili öğretimi açısından işlevselliği. Hasan Ali Yücel Ĕ̆itim Fakültesi Dergisi, 7(1), 31-48.

İngiltere Ulusal Eğitim Programı (The National Curriculum in England) (2014). English programmes of study: key stage 4. Department for Education.

McMillan, J. H., \& Schumacher, S. (2006). Research in education: evidence-based inquiry (6th. Ed.). Boston: Pearson Education Inc.

MEB (Millî Eğitim Bakanlığı) (2018a). Türkçe dersi öğretim programı (ilkokul ve ortaokul 1, 2, 3, 4, 5, 6, 7 ve 8 . Sınıflar). Ankara: Millî Eğitim Bakanlığı.

MEB (Millî Eğitim Bakanlığı) (2018b). Ortaöğretim Türk dili ve edebiyatı dersi $(9,10,11$ ve 12 . stnıflar) ögretim programı. Ankara: Millî Eğitim Bakanlığı.

Merriam, S. B. (2013). Nitel araştırma: desen ve uygulama için bir rehber. (Çev. Edt.: Prof. Dr. Selahatin Turan). Ankara: Nobel Akademik Yayıncılık.

Miles, B., \& Huberman, M. (2015). Genişletilmiş bir kaynak kitap: nitel veri analizi (Çev. Ed: Sadegül Akbaba Altun - Ali Ersoy). Ankara: Pegem Akademi.

Nolen-Hoeksema, S., Fredrickson, B. L., Loftus, G. R., \& Wagenaar, W. A. (2009). Atkinson \& hilgard's introduction to psychology (15th Edition). Bath: Wadsworth Cengage Learning.

Patton, M. Q. (2014). Nitel araştırma ve değerlendirme yöntemleri (3. Baskıdan Çeviri). (Çeviri Edt: Mesut Bütün, Selçuk Beşir Demir). Ankara: Pegem Akademi.

TDK (Türk Dil Kurumu) (2018). Türk dil kurumu güncel Türkçe sözlük. (Erişim Tarihi: 15.07.2018), http://www.tdk.gov.tr/index.php?option=com_gts\&ara ma=gts\&guid=TDK.GTS.5bc877c5d85434.41332677

Topbaş, S. (1998). Dil, anadili ve türkçe öğretimi. Türkçe ögretimi (Editör: Seyhun Topbaş). Eskişehir: Anadolu Üniversitesi Yayını.

Yaman, H., \& Demirtaş, T. (2013). Ana dili öğretim programlarının temel özellikleri. İçinde: Dünyada ana dili ögretimi -program incelemeleri- (Editör: Havva Yaman). 4-22. Ankara: Pegem Akademi.

Yaşar, Ş. (2008). Türkçe dersinin tanımı, kapsamı, önemi ve ilköğretim programlarındaki yeri. İçinde: Türkçe ögretimi (Edt.: Hülya Pilancı). Eskişehir: Anadolu Üniversitesi Yayını.

Yıldırım, A., \& Şimşek, H. (2006). Sosyal bilimlerde nitel araştırma yöntemleri (6. Baskı). Ankara: Seçkin Yayıncılık. 